$\underline{\text { ARTIGOS }}$

\title{
Biocontrol of Sclerotinia sclerotiorum and white mold of soybean using saprobic fungi from semi-arid areas of Northeastern Brazil
}

\author{
Daiane Cristina Martins Barros ${ }^{1}$, Inês Cristina de Batista Fonseca ${ }^{1}$, Maria Isabel Balbi-Peña ${ }^{1}$, Sérgio Florentino \\ Pascholati ${ }^{2}$, Douglas Casaroto Peitl ${ }^{1}$.
}

\begin{abstract}
${ }^{1}$ Departamento de Agronomia, Universidade Estadual de Londrina, 86051-970, Londrina, PR, Brasil; ${ }^{2}$ Universidade de São Paulo, Escola Superior de Agricultura Luiz de Queiroz, 13418-900, Piracicaba, SP, Brasil

Autor para correspondência: Maria Isabel Balbi-Peña (mariabalbi@uel.br)

Data de chegada: 25/03/2015. Aceito para publicação em: 23/09/2015.
\end{abstract}

$10.1590 / 0100-5405 / 2086$

\section{ABSTRACT}

Barros, D.C.M.; Fonseca, I.C.B; Balbi-Peña, M.I.; Pascholati, S.F.; Peitl, D.C. Biocontrol of Sclerotinia sclerotiorum and white mold of soybean using saprobic fungi from semi-arid areas of Northeastern Brazil. Summa Phytopathologica, v.41, n.4, p.251-255, 2015.

The incidence and the levels of yield loss caused by the white mold of soybean (caused by the fungus Sclerotinia sclerotiorum) have increased in areas of higher altitude at Cerrado and Southern Brazil, causing yield losses of up to $60 \%$. The aim of this study was to select saprobic fungi with the potential to control the white mold of soybean. First, in vitro antagonism screening was carried out to test eight saprobic fungi against S. sclerotiorum. Assessment of S. sclerotiorum mycelial growth was done at four and seven days after its placement on the culture medium. The isolate showing greatest antagonistic effect in all tests/assessments was
Myrothecium sp. An in vivo experiment was conducted in a greenhouse and growth chamber, where plants previously treated with eight saprobic fungi were artificially inoculated with $S$. sclerotiorum. The fungal culture medium (potato-dextrose) and the commercial resistance inducer acibenzolar-Smethyl were used as controls. In the in vivo tests, severity of the white mold was assessed at 8,14 and 21 days after inoculation. The highest reduction percentage in the lesion length was observed for the treatment with Myrothecium sp. (70\%), which has the greater potential to be used as biocontrol agent of soybean under the conditions of this experiment.

Keywords: biological control, Glycine max, white mold

\section{RESUMO}

Barros, D.C.M.; Fonseca, I.C.B; Balbi-Peña, M.I.; Pascholati, S.F.; Peitl, D.C. Biocontrole de Sclerotinia sclerotiorum e do mofo branco em soja usando fungos sapróbios do semi árido nordestino do Brasil. Summa Phytopathologica, v.41, n.4, p.251-255, 2015.

A incidência e os níveis de dano do mofo branco da soja (causado pelo fungo Sclerotinia sclerotiorum) têm aumentado nas áreas de maior altitude do cerrado e da região sul do Brasil, causando reduções de produtividade de até $60 \%$. O trabalho objetivou selecionar fungos sapróbios com potencial de controle do mofo-branco da soja. Primeiramente, realizou-se teste de antagonismo in vitro onde testaram-se oito espécies de fungos sapróbios em confrontação com $S$. sclerotiorum. A avaliação do crescimento micelial de $S$. sclerotiorum foi realizada aos quatro e sete dias após a repicagem. O isolado de maior efeito antagônico em todos os ensaios/avaliações foi Myrothecium sp.
Realizou-se ensaio em casa de vegetação e fitotron onde plantas tratadas com oito fungos sapróbios foram artificialmente inoculadas com S. sclerotiorum. Como controle foram utilizados o meio de cultura dos fungos (batata-dextrose) e o indutor comercial de resistência Acibenzolar-S-metílico. No teste in vivo, a severidade do mofo branco foi avaliada aos 8, 14 e 21 dias após a inoculação. A maior porcentagem de redução do comprimento da lesão foi observada para o tratamento com Myrothecium sp. (70\%); o qual apresenta o maior potencial de utilização como biocontrolador de $S$. sclerotiorum nas condições do experimento.

Palavras-chave: controle biológico, Glycine max, mofo-branco.

White mold is caused by Sclerotinia sclerotiorum (Lib.) De Bary and is present in all Brazilian regions with mild climate conditions (southern Brazil and cerrado highlands above $800 \mathrm{~m}$ of altitude). In addition to soybean (Glycine max L.), white mold attacks a vast range of crops and weeds, but not grasses (4). The incidence and the level of losses of white mold of soybean has recently increased, cutting yields by up to $60 \%$. It is estimated that around $25 \%$ of the Brazilian soybean area is infested with this pathogen (20).

Once established, S. sclerotiorum is difficult to eradicate. Control methods include the use of certified seeds, soybean rotation/succession with maize, white oats or wheat, and elimination of weeds, the majority of which are hosts for the fungus and other pathogens (4). At present, no cultivars genetically resistant to $S$. sclerotiorum are available, but individual cultivars can differ significantly in susceptibility (12). Saprobic fungi have recently attracted special attention as biological control agents and potential resistance inducers (22) since, like plant pathogenic fungi, they are capable of secreting pectinases, inducing the release of oligogalacturonides and activating the plant defense response. Fungal biodiversity prospecting has been conducted in semiarid areas and various saprobic fungi were identified in the litter of 
the Caatinga forest in northeastern Brazil $(3,6,14,16)$. Within the framework of the SISBIOTA Program (CNPq/FAPESP), some of these fungi were tested for their ability to control some infectious diseases in various crops. The aim of this study was therefore to select saprobic fungi with the potential to control white mold of soybean.

\section{MATERIAL AND METHODS}

Antagonism tests were performed with eight species of saprobic fungi deposited on the "Coleção de Culturas de Microrganismos da Bahia (CCMB)" at the "Universidade Estadual de Feira de Santana", Bahia State, Brazil (CNPQ Process Number 010044/2014-0). Species were identified by comparing their reproductive structures with the descriptions in the specialized bibliography (3).

A completely randomized experimental design with five replicates was used. The tested saprobic fungi were: Pithomyces chartarum (PIC), Myrothecium sp. (MY), Curvularia inaequalis (CUI), Curvularia eragrostidis (CUE), Stachybotrys globosa (STG), Memnoniella echinata (MEE), Memnoniella levispora (MEL) and Stachylidium bicolor (STB).

To test the antagonism between each of the fungi and the phytopathogenic fungus, we used the paired culture method (8) with modifications. The saprobic fungi were cultured at $25 \pm 2{ }^{\circ} \mathrm{C}$ and $12 / 12$ photoperiod for 15 days, and the phytopathogenic fungus, $S$. sclerotiorum, at $20 \pm 2{ }^{\circ} \mathrm{C}$ and $12 / 12$ photoperiod for seven days, both on potato-dextrose-agar (PDA) culture medium.

A mycelial disc of the saprobic fungus was placed at approximately $1 \mathrm{~cm}$ from the edge of the plate containing PDA medium. Since saprobic fungi grow slowly, S. sclerotiorum was placed opposite from the saprobics at seven days later. However, for Curvularia eragrostidis and C. inaequalis, the $S$. sclerotiorum disc was placed on the plate at only three days after these saprobics, which are known to grow faster than the others. The distance between the saprobic mycelial disc and the $S$. sclerotiorum disc was 6 centimeters. Control plates contained pathogen discs only. The plates were sealed with plastic film and kept at $20 \pm 2$ ${ }^{\circ} \mathrm{C}$ under a 12/12 photoperiod. On the fourth and seventh day after $S$. sclerotiorum disc placement, the diameter of the fungal colonies was measured. The inhibition halo was determined by subtracting the sum of the mycelial growth of the saprobics and the pathogen from the total diameter of the plate. The results underwent analysis of variance and the data were compared according to Tukey's test at a 0.05 confidence level. The experiment was repeated three times.

To assess the control of the saprobic fungi on white mold of soybean, an in vivo test was carried out from March to May 2013. A completely randomized experimental design with eight treatments (saprobic fungi) and four replicates was used, and the experimental unit consisted of a pot containing two soybean plants.

Five seeds of the soybean cultivar BMX Potência RR were sown in 5-liter pots containing sand and soil (3:1 mix) and $15 \mathrm{~g}$ NPK (4-1408 ) fertilizer. The plantlets were thinned at fifteen days after sowing, leaving two plants in each pot. From sowing to inoculation (stage R1), the plants were kept in the greenhouse at an average temperature of $27.2^{\circ} \mathrm{C}$ under natural sunlight and were watered daily.

To culture the saprobic fungi, two 5-mm diameter mycelium discs were removed from the edge of the colonies grown for one month and placed inside Erlenmeyer flasks containing $100 \mathrm{~mL}$ liquid potatodextrose medium. The cultures were kept undisturbed in a chamber at $25{ }^{\circ} \mathrm{C}$ for seven days; then, $100 \mathrm{~mL}$ sterilized distilled water were added to the fungal cultures. The suspensions were homogenized in a liquidizer and applied to the soybean plants. Treatments were applied on leaves of soybean plants at stage V5/V6 by using cotton wool dipped in the suspension and gently rubbed on the abaxial and adaxial leaf surfaces. Treatments consisted of the saprobic fungi used in the antagonism test, a commercial plant resistance inducer (acibenzolarS-methyl, commercial name Bion $\left.{ }^{\circledR}\right)$, liquid potato-dextrose medium and an untreated control. One drop per liter of Tween 20 was added to all suspensions. The Bion ${ }^{\circledR}$ treatment was equivalent to $7.5 \mathrm{~g}$ a. i./ha.

At three days after treatment with the saprobics, the plants were inoculated with $S$. sclerotiorum, according to the method of Kull et al. (15) with modifications. For inoculation, a $200-\mu \mathrm{L}$ micropipette tip was used to remove the inoculum from three-day-old colonies of $S$. sclerotiorum on PDA $\left(20 \pm 2{ }^{\circ} \mathrm{C}\right.$ and $12 / 12$ photoperiod $)$. These tips containing the inoculum were placed on the cut stems of the soybean plants. The stems were previously cut with sterilized scissors at $0.5 \mathrm{~cm}$ above the last fully expanded leaf insertion $\left(5-6^{\text {th }}\right.$ trifoliolate leaves $)$.

After inoculation, the plants were transferred to a growth chamber at $20 \pm 1{ }^{\circ} \mathrm{C}, 12 / 12$ photoperiod, where they were kept for seven days. During the first $48 \mathrm{~h}$, the plants were water sprayed to maintain the high humidity and stimulate the development of disease symptoms. On the eighth day, the plants were returned to the greenhouse under the conditions described above.

At 8, 14 and 21 days after inoculation (DAI), the length of the lesions caused by $S$. sclerotiorum was measured $(\mathrm{cm})$ from the cut end of the stem to the end of the lesion, according to Kull et al. (15). The area under disease progress curve (AUDPC) (10) was calculated based on the formula $=\Sigma[((\mathrm{y} 1+\mathrm{y} 2) / 2) *(\mathrm{t} 2-\mathrm{t} 1)]$, where $\mathrm{y} 1$ and $\mathrm{y} 2$ are two consecutive measurements made at times $t 1$ and $t 2$, respectively. The results underwent analysis of variance and data were compared according to Tukey's test at a 0.05 confidence level.

\section{RESULTS AND DISCUSSION}

The results of the antagonism test indicate that $S$. sclerotiorum mycelial growth was affected by the saprobic fungi (Figure 1, Table 1). The isolate that provided the greatest antagonistic effect in all the tests and evaluations was Myrothecium sp. In both assessments of experiment 1, in addition to Myrothecium sp., the isolates Pithomyces chartarum, Stachybotrys globosa and Memnoniella levispora showed an antagonistic effect. For experiment 2, in addition to Myrothecium sp., the isolates Pithomyces chartarum, Stachybotrys globosa and Memnoniella echinata showed an antagonistic effect in the first assessment, but only Myrothecium sp. and Memnoniella echinata maintained the inhibition of $S$. sclerotiorum mycelial growth in the subsequent evaluation. For experiment 3, in addition to Myrothecium sp., the isolates Pithomyces chartarum, Stachybotrys globosa, Memnoniella echinata, Memnoniella levispora and Stachylidium bicolor inhibited S. sclerotinia mycelial growth in the first evaluation, but this effect did not last for Stachylidium bicolor in the second assessment. According to Ahmed et al. (1), antifungal metabolites diffused in the culture medium inhibit mycelial growth by disorganizing the cells and causing lysis of the hyphae in the culture medium.

Balbi-Peña et al. (5) conducted antagonism test between saprobic fungi and S. sclerotiorum on three different culture media (potatodextrose-agar; carrot-agar and Pontecorvo minimal medium) and observed that Dictyochaeta simplex, Stachybotrys nephrosfora, S. globosa, Memnoniella levispora and M. echinata inhibited the mycelial growth of the pathogen on at least 2 of the 3 tested media. In our study, although treatments with $S$. globosa, M. levispora and M. echinata inhibited the mycelial growth in at least 2 of the 3 tests (Table 1), these 


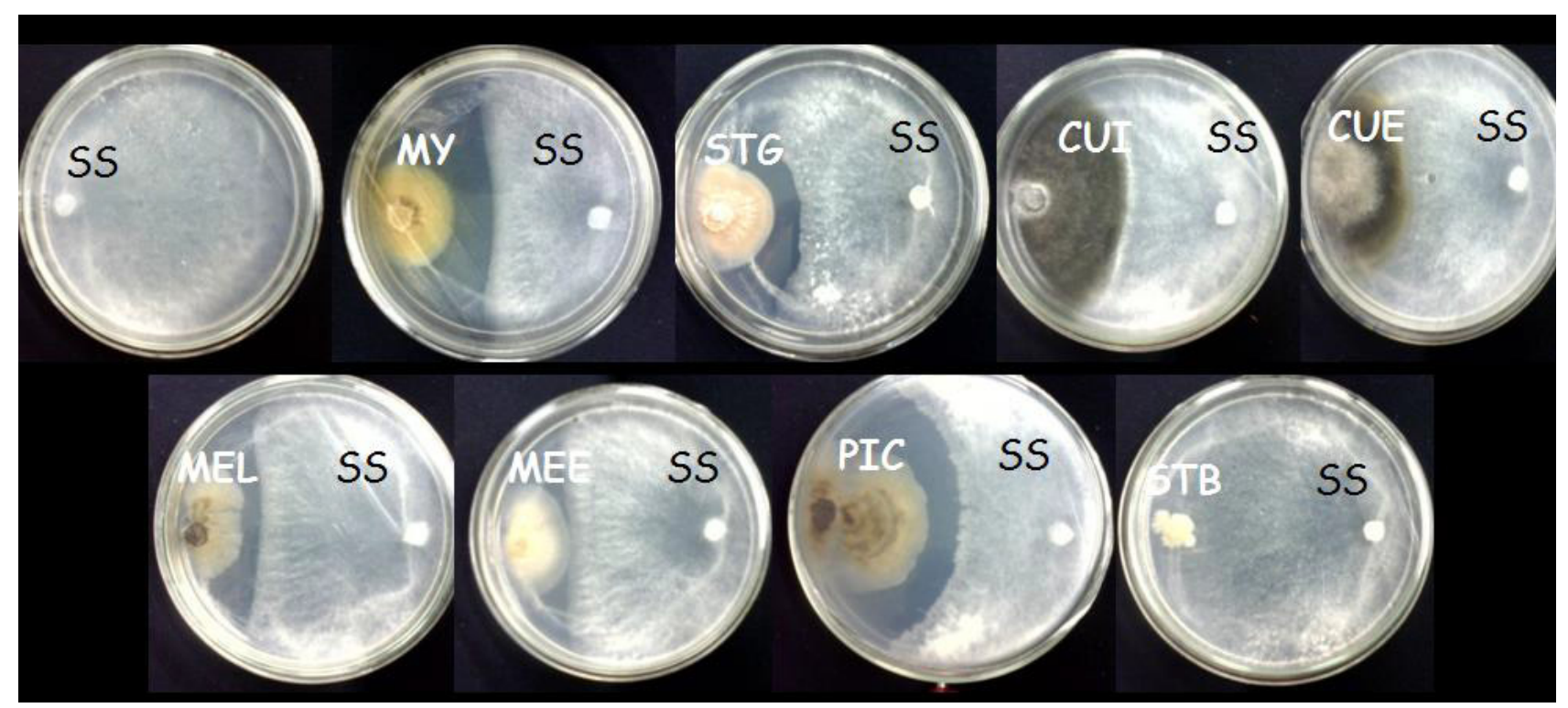

Figure 1. Development of Sclerotinia sclerotiorum (SS) in the antagonism test (direct confrontation) with the saprobic fungi Myrothecium sp. (MY), Stachybotrys globosa (STG), Curvularia inaequalis (CUI), Curvularia eragrostidis (CUE), Memnoniella levispora, (MEL), Memnoniella echinata (MEE), Pithomyces chartarum (PIC) and Stachylidium bicolor (STB) at four days after the placement of S. sclerotiorum.

Table 1. Size of the mycelial growth inhibition halo of Sclerotinia sclerotiorum in antagonism tests with saprobic fungi isolates.

\begin{tabular}{|c|c|c|c|c|c|c|}
\hline \multirow{2}{*}{ Treatment } & $\mathrm{E} 1 \mathrm{~A} 1^{(1)}$ & E1A2 & E2A1 & E2A2 & E3A1 & E3A2 \\
\hline & \multicolumn{5}{|c|}{ Mycelial growth inhibition halo $(\mathrm{cm})$} & \\
\hline $\mathrm{PIC}^{(2)}$ & $0.7 b^{(3)}$ & $0.7 \mathrm{~b}$ & $0.7 \mathrm{~b}$ & $0.4 \mathrm{bc}$ & $1.4 \mathrm{ab}$ & $1.5 \mathrm{ab}$ \\
\hline CUI & $0.0 \mathrm{~d}$ & $0.0 \mathrm{~d}$ & $0.0 \mathrm{c}$ & $0.0 \mathrm{~d}$ & $0.0 \mathrm{c}$ & $0.0 \mathrm{c}$ \\
\hline CUE & $0.0 \mathrm{~d}$ & $0.0 \mathrm{c}$ & $0.0 \mathrm{c}$ & $0.2 \mathrm{~cd}$ & $0.3 \mathrm{c}$ & $0.2 \mathrm{c}$ \\
\hline MEE & $0.0 \mathrm{~d}$ & $0.0 \mathrm{c}$ & $0.9 \mathrm{~b}$ & $0.6 \mathrm{~b}$ & $2.1 \mathrm{ab}$ & $1.2 \mathrm{~b}$ \\
\hline MEL & $0.6 \mathrm{bc}$ & $0.6 \mathrm{~b}$ & $0.2 \mathrm{c}$ & $0.0 \mathrm{~d}$ & $2.0 \mathrm{ab}$ & $1.1 \mathrm{~b}$ \\
\hline STB & $0.3 \mathrm{c}$ & $0.0 \mathrm{c}$ & $0.0 \mathrm{c}$ & $0.0 \mathrm{~d}$ & $1.1 \mathrm{~b}$ & $0.0 \mathrm{c}$ \\
\hline TEST & $0.0 \mathrm{~d}$ & $0.0 \mathrm{c}$ & $0.0 \mathrm{c}$ & $0.0 \mathrm{~d}$ & $0.0 \mathrm{c}$ & $0.0 \mathrm{c}$ \\
\hline CV (\%) & 31.4 & 26.3 & 34.5 & 37.7 & 27.8 & 21.1 \\
\hline
\end{tabular}

(1) $\mathrm{E}=$ experiment and $\mathrm{A}=$ assessment (A1- 4 days after placement; $\mathrm{A} 2$ - 7 days after placement)

(2) Pithomyces chartarum (PIC), Myrothecium sp. (MY), Curvularia inaequalis (CUI), Curvularia eragrostidis (CUE), Stachybotrys globosa (STG), Memnoniella echinata (MEE), Memnoniella levispora (MEL), Stachylidium bicolor (STB) and Control (TEST).

(3) Means followed by the same letter in the column are not significantly different according to Tukey's test at $5 \%$ probability.

were not the treatments with the strongest antagonistic effect.

Silva et al. (21) assessed the antagonistic effect of the saprobics Curvularia inaequalis, Dictyochaeta simplex, Gonytrichum macrocladum, Memnoniella echinata, Pseudobotrytis terrestris, Stachybotrys globosa and S. nephrosfora against Elsinoe ampelina, which causes anthracnose in grapevines. They observed that, on a PDA medium, Memnoniella echinata produced a 7.1-mm halo, in contrast to the 1.27-mm halo produced by Stachybotrys globosa. Alencar et al. (2), evaluating the antagonistic effect of Curvularia eragrostidis, $C$. inaequalis, Memnoniella echinata, M. levispora, Stachybotrys globosa, S. nephosfera, Pithomyces chartarum and Pseudobotrytis terrestris against Septoria lycopersici, observed that $C$. eragrostidis inhibited pathogen mycelial growth by $20.9 \%$.

In the in vivo test, the lesions observed on the main stems were straw colored and the affected stem was hollow and brittle. In the first evaluation (8 DAI), the leaves were wilted and in the second evaluation (14 DAI) many of them were already dried up and brittle. In the initial evaluation, some plants exhibited sclerotia, while in the second evaluation, although the number of plants showing mycelial growth over the lesion was greater than in the first evaluation, the number of formed or developing sclerotia had not increased significantly.

The length of the lesions caused by $S$. sclerotiorum was affected by the saprobic fungal treatment applied prior to the inoculation with $S$. sclerotiorum (Table 2). Treatment with Myrothecium sp. was the only 
Table 2: Lesion length $(\mathrm{cm})$, area under disease progress curve (AUDPC) and lesion length reduction percentage at 21 days after inoculation (DAI) in soybean plants treated with saprobic fungi and inoculated with Sclerotinia sclerotiorum. Londrina-PR. Mar-May, 2013.

\begin{tabular}{|c|c|c|c|c|c|}
\hline \multirow{2}{*}{ Treatment } & \multicolumn{3}{|c|}{ Lesion length $(\mathrm{cm})$} & \multirow{2}{*}{ AUDPC $^{(2)}$} & \multirow{2}{*}{$\%$ Reduction at 21 DA } \\
\hline & $8 \mathrm{DAI}^{(1)}$ & 14 DAI & 21 DAI & & \\
\hline $\mathrm{PIC}^{(3)}$ & $2.5 a b^{(4)}$ & $3.5 \mathrm{a}$ & $3.8 \mathrm{a}$ & $3.1 \mathrm{ab}$ & 61.6 \\
\hline MY & $0.7 \mathrm{a}$ & $2.1 \mathrm{a}$ & $3.0 \mathrm{a}$ & $1.7 \mathrm{a}$ & 70.0 \\
\hline CUI & $4.5 a b$ & $5.9 \mathrm{a}$ & $7.3 \mathrm{a}$ & $5.5 a b$ & 27.4 \\
\hline CUE & $1.8 \mathrm{ab}$ & $2.2 \mathrm{a}$ & $3.1 \mathrm{a}$ & $2.2 a b$ & 69.0 \\
\hline STG & $4.6 a b$ & $6.6 \mathrm{a}$ & $8.1 \mathrm{a}$ & $4.1 \mathrm{ab}$ & 19.1 \\
\hline MEE & $2.9 a b$ & $3.7 \mathrm{a}$ & $5.0 \mathrm{a}$ & $3.6 a b$ & 50.2 \\
\hline MEL & $5.0 \mathrm{ab}$ & $6.5 \mathrm{a}$ & $7.9 \mathrm{a}$ & $6.1 \mathrm{ab}$ & 21,0 \\
\hline STB & $3.9 a b$ & $6.4 \mathrm{a}$ & $8.2 \mathrm{a}$ & $5.7 a b$ & 18.4 \\
\hline PD & $3.4 a b$ & 5. $7 \mathrm{a}$ & $7.5 \mathrm{a}$ & $5.1 \mathrm{ab}$ & 25.4 \\
\hline ASM & $5.4 a b$ & $6.9 \mathrm{a}$ & $8.5 \mathrm{a}$ & $6.5 a b$ & 14.9 \\
\hline Control & $5.8 \mathrm{~b}$ & $8.0 \mathrm{a}$ & $10.0 \mathrm{a}$ & $7.4 \mathrm{~b}$ & 0.0 \\
\hline CV (\%) & 29.8 & 29.5 & 29.4 & 29.1 & \\
\hline
\end{tabular}

Data were transformed by using “ $(\mathrm{x}+\mathrm{k}) \wedge 1 / 2$ ” where $\mathrm{k}=0.1$

(1) DAI: days after inoculation

(2) $\mathrm{AUDPC}=\Sigma[((\mathrm{y} 1+\mathrm{y} 2) / 2) *(\mathrm{t} 2-\mathrm{t} 1)]$

(3) Pithomyces chartarum ( PIC), Myrothecium sp (MY), Curvularia inaequalis (CUI), Curvularia eragrostidis (CUE), Stachybotrys globosa (STG), Memnoniella echinata (MEE), Memnoniella levispora (MEL), Stachylidium bicolor (STB), liquid potato-dextrose medium (PD), acibenzolar-S-methyl (ASM).

(4) Means followed by the same letter in the column are not significantly different according to Tukey's test at $5 \%$ probability.

one that statistically differed from the control in the initial evaluation. In subsequent evaluations, there was no significant difference. However, based on the area under the disease progress curve (AUDPC) for the various treatments (Table 2), Myrothecium sp. statistically differed from the control. At 21 DAI, treatment with Myrothecium sp. reduced the lesion length by $70 \%$, compared to the control (Table 2). These results suggest that the applied treatment initially controlled the disease, but this protection did not last and became less effective as the disease developed. However, it was enough to delay the progress of the infection. Reapplying the treatment could provide greater protection, as observed with the use of chemicals, which normally need to be reapplied during the disease cycle.

Other studies using species belonging to the genus Myrothecium to control plant pathogenic fungi have been conducted and some promising results obtained. Gees \& Coffey (13) assessed the potential of a strain of $M$. roridum as a biocontrol agent for Phytophthora cinnamomi and found that zoospore germination was completely inhibited. Lian et al. (17) showed that two antifungal trichothecenes, roridin A and roridin D, produced by Myrothecium sp. isolated from marine sponge Axinella sp., showed potential as inhibitors of the plant pathogen S. sclerotiorum. M. verrucaria has been used to control nematodes, marketed as Ditera ${ }^{\circledR}$, the main active ingredient of which is a mixture of inactivated fungus and the medium in which the fungus was grown. This product is marketed in Costa Rica, USA, Honduras, Mexico, Guatemala, Panama, Chile and other countries (9).

Liu et al. (18) studied the effect of metabolites produced by Myrothecium sp. on Candida albicans, Aspergillus niger and Trichophyton rubrum. Fungal metabolites roridin A and 8 $\beta$-acetoxyroridin $\mathrm{H}$ were bioactive against the three fungi, with control levels close to those of the antifungal pharmaceutical ketoconazole, used as a positive control. Bearing in mind that C. albicans, $A$. niger and T. rubrum are very common opportunistic human pathogens, the importance of the metabolites produced by the genus
Myrothecium goes beyond its potential for controlling plant diseases. Marba et al. (19), evaluating the effect of Stachybotrys globosa, S. nephrosfora and Memnoniella echinata on Colletotrichum gloeosporioides, observed that $M$. echinata had a significant control of C. gloeosporioides in inoculated grapes. The disease index was $25.21 \%$ when the saprobic was sprayed onto the grapes at four hours after inoculation with the pathogen, $28.33 \%$ when spraying and inoculation were performed simultaneously and $50.83 \%$ for the inoculated control.

In our study, Acibenzolar-S-methyl (ASM) did not inhibit the development of $S$. sclerotiorum. This result backs up those obtained by Carvalho et al. (11) in the evaluation of Asian soybean rust control by using Acibenzolar-S-methyl defense activator and a leaf fungicide. Those authors observed that up to three applications of Acibenzolar-Smethyl were not effective in controlling Asian soybean rust. Similarly, studying foliar application of Acibenzolar-S-methyl to induce resistance to Asian soybean rust and Cercospora leaf spot in maize, Barros (7) found that ASM application did not control the disease, whether used alone or combined with the fungicides tested on both pathosystems.

Based on the results obtained in the antagonism tests, we can conclude that Myrothecium sp. shows the greatest antagonistic effect in all the tests and evaluations. Pithomyces chartarum, Memnoniella echinata, M. levispora and Stachybotrys globosa show potential for in vitro control of $S$. sclerotiorum, inhibiting the phytopathogenic fungus in at least one of the conducted tests.

The in vivo experimental results demonstrated that the saprobic fungus Myrothecium sp. shows potential as a biocontrol agent of white mold of soybean. To determine how feasible the use of Myrothecium $\mathrm{sp}$. is in practice, further field studies are required to test the number of applications, and when and how to apply the saprobic fungi. 


\section{ACKNOWLEDGEMENTS}

The first author would like to thank CAPES ("Coordenação de Aperfeiçoamento de Pessoal de Nível Superior”), for the scholarship, and Professor Dr. Luis Fernando P. Gusmão, in charge of the fungal collection at "Universidade Estadual de Feira de Santana" (Bahia -Brazil), for providing the saprobic fungi used in this study.

\section{REFERENCES}

1. Ahmed, A.S.; Ezziyyani, C.; Sánchez, C.P.; Candela, M.E. Effect of chitin on biological control activity of Bacillus spp. and Trichoderma harzianum against root rot disease in pepper (Capsicum anпииm) plants. European Journal of Plant Pathology, Wageningen v.109, p. 633-637, 2003.

2. Alencar, M.S.R.; Solino, A.J.S.; Schwan-Estrada, K.F.; Pascholati, S. F. Antagonismo in vitro de fungos sapróbios a Septoria lycopersici. In: Congresso Brasileiro de Fitopatologia, 45. Manaus, AM. Tropical Plant Pathology. Brasília v. 37, suplemento, p. 313, ago. 2012. In: http://www. sbfito.com.br/tpp/Suplemento_2012_Manaus.pdf, Acesso em: 17 ago 2015.

3. Almeida, A.A.C de.; Izabel, T. dos S.S.; Gusmão, L.F.P. Fungos conidiais do bioma Caatinga I. Novos registros para o continente americano, Neotrópico, América do Sul e Brasil. Rodriguésia, Rio de Janeiro v.62, n. 2, p. 043-053, abr/jun., 2011.

4. Almeida, A.M.R.; Ferreira, L.P.; Yorinori, J.T.; Silva, J.F.V.; Henning, A.A.; Godoy, C.V.; Costamilan, L.M.; Meyer, M.C. Doenças da soja. In: Kimati, H.; Amorim, L.; Rezende, J.A.M.; Bergamin Filho, A.; Camargo, L.E.A. Manual de Fitopatologia: doenças das plantas cultivadas. 4a Ed., Vol. 2, São Paulo - SP: Editora Agronômica Ceres Ltda. 663p. 2005. p. 569-588.

5. Balbi-Peña, M.I.; Mello, F.E.; Peitl, D.C.; Calvo, N.S.; Araujo, F.A.; Sumida, C.H. Teste de confrontação direta entre fungos sapróbios e Sclerotinia sclerotiorum em diferentes meios de cultura. In: Congresso Brasileiro de Fitopatologia, 45. Manaus, AM. Tropical Plant Pathology. Brasília v. 38, suplemento, p. 476, ago. 2012. In: http://www.sbfito.com.br/tpp/Suplemento_2012_Manaus.pdf, Acesso em: 17 ago 2015.

6. Barbosa, F.R.; Gusmão, L.F.P. Conidial fungi from semi-arid Caatinga Biome of Brazil. Rare freshwater hyphomycetes and other new records. Mycosphere, Chiang Rai v.2, n.4, p.475-485, 2011.

7. Barros, R. Estudo sobre a aplicação foliar de Acibenzolar-s-metil para indução de resistência à ferrugem asiática em soja e cercosporiose em milho. Arquivos do Instituto Biológico, São Paulo, v.78, n.4, p.519-528, out./dez., 2011.

8. Bell, D.K.; Wells, H.D.; MarkhabelL, D.K.; Wells, C.R. In vitro antagonism of Trichoderma species against six fungal plant pathogens. Phytopathology, Saint Paul, v.72, n.4, p.379-382, 1982.

9. Bettiol, W.; Morandi, M.A.B.; Pinto, Z.V.; Paula Júnior, T.J de. Corrêa, E.B.; Moura, A.B.; Lucon, C.M.M.; Costa, J.C.B.; Bezerra, J.L. Produtos comerciais à base de agentes de biocontrole de doenças de plantas. Jaguariúna, SP: Embrapa Meio Ambiente, 2012. 155 p.
10. Campbell, C.L.; Madden, L.V. (Ed.). Introduction to plant disease epidemiology. New York, NY: Wiley, 1990. 532 p.

11. Carvalho, B.O.; Oliveira, J.A.; Carvalho, E.R.; Andrade, V. de.; Ferreira, T. F.; Reis, L. V. Action of defense activator and foliar fungicide on the control of Asiatic rust and on yield and quality of soybean seeds. Journal of Seed Science, Londrina v.35, n.2, p.198-206, 2013.

12. Furlan, S.H. Manejo do mofo-branco na cultura da soja. Número 111, julho 2009. Disponível em: http://www.biologico.sp.gov.br/artigos_ok.php?id_artigo=111. Acesso em: 30 jul. 2013.

13. Gees, R. Coffey, M. D. 1989. Evaluation of a strain of Myrothecium roridum as a potential biocontrol agent against Phytophthora cinnamomi. Phytopathology, Saint Paul v.79, p. 1079-1084, 1989.

14. Izabel, T dos S.S.; Santos, D.S.; Almeida, D.A.C de.; Gusmão, L.F.P. Fungos conidiais do bioma Caatinga II. Novos registros para o continente americano, Neotrópico, América do Sul e Brasil. Rodriguésia, Rio de Janeiro, v.62, n. 2, p. 229-240, abr/jun., 2011.

15. Kull, L.S.; Vuong, T.D.; Powers, K.S.; Eskridge, K.M.; Steadman, J.R.; Hartman, G.L. Evaluation of resistance screening methods for Sclerotinia stem rot of soybean and dry bean. Plant Disease, Saint Paul v. 87, p. 1471-1476, 2003.

16. Leão-Ferreira, S.M.; Gusmão, L.F.P.; Ruiz, R.F.C. Conidial fungi from the semi-arid Caatinga biome of Brazil. Three new species and new records. Nova Hedwigia, Stuttgart v. 96, p. 479-494, jan. 2013.

17. Lian, W. X.; Shu, M.J.; Hong, H.Z.; Wei, S.; Yong, C.O.; Shi, K.D.; Xiang, L. Potential inhibitors against Sclerotinia sclerotiorum, produced by the fungus Myrothecium sp. associated with the marine sponge Axinella sp. European Journal of Plant Pathology, Wageningen v.122, n.4, p. 571-578, dec. 2008.

18. Liu, C. H.; Huang, L. L.; Ye, Y. H.; Zou, W.X.; Guo, Z. J.; Tan, R. X. Antifungal and new metabolites of Myrothecium sp. Z16, a fungus associated with white croaker Argyrosomus argentatus. Journal of Applied Microbiology, Oxford v. 100, n. 1, p. 195-202, jan., 2006.

19. Marba, L.D.; Benato, E.A.; Valentini, S.R.T.; Castro, M.F.P.M.; Pascholati, S.F. Bioprospeç̧ão de fungos sapróbios do semi-árido nordestino para controle de Colletotrichum sp. em uva pós-colheita. In: Congresso Interinstitucional de Iniciação Científica, 6, 2012. Jaguariúna-SP. Embrapa Meio Ambiente. 2012.

20. Meyer, M.C. Manejo de mofo branco em soja. Correio do Estado, Campo Grande, 08 out. 2012. Caderno rural, p. 2. In: http://flip.siteseguro.ws/pub/ correiodoestado/index.jsp?ipg=97939, Acesso em: 31 jul 2013.

21. Silva, C.M.DA.; Schwan-Estrada, K.R.F.; Rodrigues, M.S.; Faria, C.M.D.R.; Pascholati, S.F. Potencial antagônico de fungos sapróbios do Semiárido Nordestino contra Elsinoe ampelina. In: Congresso Brasileiro de Fitopatologia, 45. 2012. Manaus-AM. Tropical Plant Pathology, Brasília v. 37, suplemento, p. 473, ago. 2012. In: http://www.sbfito.com.br/tpp/Suplemento_2012_Manaus.pdf, Acesso em: 17 ago 2015.

22. Yedidia, I.; Shoresh, M.; Kerem, Z.; Benhamou, N.; Kapulnik, Y.; Chet, I. Concomitant induction of systemic resistance to Pseudomonas syringae pv. lachrymans in cucumber by Trichoderma asperellum (T-203) and the accumulation of phytoalexins. Applied and Environmental Microbiology, Washington v.69, n.12, p.7343-7353, dec., 2003. 